\title{
Transport Processes In A Heavy Eutrophic Marine Bay, Alexandria (Egypt), Applying Environmental Impact Assessment (EIA) Model
}

\author{
S.K.Mikhail, W.L.Gergis and E.E.Siam* \\ National Institute of Oceanography and Fisheries \\ *Arab Academy for Sscience and Technology and Maritime Transport
}

\begin{abstract}
Autogenous and allogenous control of the phytoplankton standing crop and biomass was proved in Mex Bay, west of Alexandria (Egypt). Among the clear signs of eutrophication are the heavy visible blooms, which became regular events, at intermittent periods during the warm seasons. The causative organisms progressed differently, the dinoflagellate, Gymnodinium catenatum, is well known toxic species.

The Environmental Impact Assessment model (EIA) was applied to Mex Bay. It is a three-dimensional water quality and flow model, based on the three interacted dimensional: longitude, latitude and depth, calculations of time and space variations. The model deals with processes that affecting the water quality. It was initiated with measured field data and load input. The model was used to simulate phytoplankton biomass transport and ambient nutrient concentrations (nitrate, phosphate \& ammonia). The model results and the field measurements are compared in order to fit the model. Generally, the calculated flow and concentrations corresponded well with observations. Deviations are attributed to several reasons. A notable influence of the main outfall on the concentrations, particularly in the near shore area, as well as, on the seawater quality was detected. The spatial distribution of the phytoplankton standing crop coincided clearly with the accompanied chlorophyll a concentrations calculated by the model. The results stressed the need to reduce load input into Mex Bay, in order to counteract eutrophication in Alexandria waters. Nitrogen reduction is more important for the whole area, while phosphorous reduction is more effective in the bay.
\end{abstract}

\section{Introduction}

Although coastal marine transiti onal ecosystems located between land and open sea represent only small area of the world's ocean, they are of great ecological and economic importance.

The land inflow of waste waters and subsequently the excessive input of nutrients, mainly nitrogen and phosp horus is underlying cause of eutroph - ication. This phenomenon is of wide occurrence in various parts of the world (Vollenweider, 1981). Over $183 \times 10^{6}$ $\mathrm{m}^{3}$ of partially treated or untreated sewage and waste waters are discharged annually into the coast of Alexandria, but mostly into it's the western part. About $40 \%$ of the industry surrou nds Alexandri city and as a conseque - 
nce of the rapid increase of the human population and other activities, the task of controlling pollution have become a serious problem. The discharge waters rendered the neritic waters of Alexandria highly eutrophic, developing the occurrence of regular toxic and/or non toxic red tide blooms (Labib, 1992; Labib, 1994, a, b; Labib, 1996; Labib \& Halim, 1995). Attempts have been made to evaluate the quantity of the different sources of pollutants, west of Alexandria (e.g. Said et al., 1991; Abdel Moneim et al., 1994; Nessim, 1994), and their ecological impacts on the standing crop (Dorgham et al., 1987; ElSherif, 1989; Samaan et al., 1992).

\section{A case study: Mex Bay}

Mex Bay has a surface area of about $19.4 \mathrm{Km}^{2}$, mean depth of about $10 \mathrm{~m}$ and a volume of about $190.3 \times 10^{6}$ $\mathrm{m}^{3}$ (Labib,1997). The bay receives directly daily agricultural discharge water, mean of $6.5 \times 10^{6} \mathrm{~m}^{3}$, (Emar, et.al 1992) from neighbouring Lake Maryout, through Umum Drain. This water is mixed with municipal and industrial wastes. Five main industries, Chemical, Chloro-alkali, Tanneries, Cement and Petroleum, dispose their waste waters directly into the western part of the bay. Due to water circulation, it is also affected by additional amount of municipal wastewater from the main sewer of Alexandria located at its eastern part.

Man-made eutrophication in Mex
Bay caused drastic environmental changes. The bay has distinct structural dynamic properties that easily differe ntiate it from the adjacent Mediter ranean open oceanographic system. It is a site of heavy phytoplankton blooms.

The aim of the present study is to set up the Environmental Impact Assessment (EIA) model to Mex Bay to: - provide an overview of the proce sses governing the transport of the dissolved inorganic nutrients (ammonia, nitrate and phosphate); and the seasonal and spatial distribution of phytoplan kton biomass (Chlorophyll a); - to determine the extent of eutrophication and to discuss the hydrodynamic characters of the bay.

The results gained can give a better insight into practical processes have to be carried out in order to ameliorate the situation, if possible. The final goal of the work is not just to study of nutrient cycles and dynamics as well as biological processes, but to predict future trends of eutrophication in changed physical and chemical conditions.

The bay is ideally suited for achieving the purposes of the study because its circulation patterns are a complicated function of winds, huge input of waste waters of different sources and pollutants and because of the ecological and economic problems associated with the progressive eutrophication.

The study is based on surface data collected during 1992-1995.

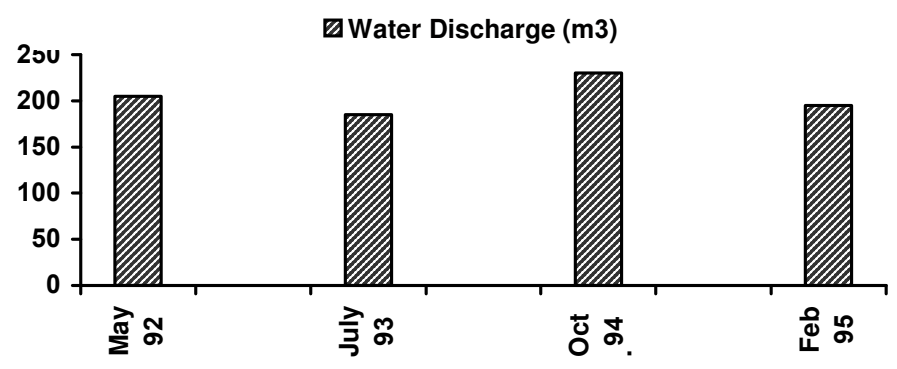

Figure 1: water discharge from Umum Drain (Nessim,1994) 


\section{Nutrient concentrations and water discharge input}

The monthly amount of the discharged water $\left(\mathrm{m}^{3}\right)$ into Mex Bay throughout Umum Drain was shown in Figure. 1. Data obtained from Ministry of Irrigation, Directorate of Mex Pumping Station, Alexandria.

The daily nutrient injection from land-based sources led to continuous regeneration of nutrient. The high ammonia, nitrate and phosphate concentrations during May 1992 and February 1995 (ammonia reached 60.5 $\mu$ mol. $1^{-1}$ during the latter month), associated with peaks of discharge water input, and very limited phytoplankton growth. However, severe impoverishment occurred during the red tide bloom periods in July 1993 and October 1994 (ammonia and nitrate at 4.2 and $3.5 \mu$ mol. $\mathrm{l}^{-1}$ during the latter month, respectively).

\section{Phytoplankton standing crop, species composition and chlorophyll a}

The phytoplankton standing crop and species composition progressed differently during the different months. The density was relatively low in May 1992, attaining $0.12 .10^{6}$ cell. $1^{-1}$. The community was mainly represented by microflagellate species, $56.54 \%$ to the total standing crop, followed by Scendesemus quadricauda (12.91\%), Protoperidinium steinii (4.9\%) and Prorocentrum minimum (3.8\%). However, chlorophyll a was relatively high $\left(7.3 \mu \mathrm{g} .1^{-1}\right)$, influenced by the occurrence of fresh-water forms, mainly, Euglena acus and E. gracilis.. A water discoloration was observed on 12 July 1993, the centric diatom, Skeletonema costatum, culminating a population size at $12.10^{6}$ cell. $1^{-1}$, $96.2 \%$.Chlorophyll a reached its maximum of $33.8 \mu \mathrm{g} . \mathrm{l}^{-1}$. The accomp anied minor species were Rhizosolenia fragilissima, Scrippsiella trochoidea and Prorocentrum triestinum. Again, 5-11 October 1994 was a bloom period (maximum 44.2.10 cell. $^{-1}$ ), Gymno dinium catenatum $(53.13 \%)$, and Euglena granulata $(26.56 \%)$, were the responsible species. Chlorophyll a content attained $27.3 \mu \mathrm{g}$. 1 $^{-1}$. These previous blooms covered the entire bay, but with different degrees. The western area was always dense. The phytoplankton standing crop was very poor in February $\left(70.1 .10^{3}\right.$ cell. $\left.1^{-1}\right)$, despite the remarkable nutrients incr ease, Phacus triquter contributed $51 \%$ to the total. Temperature was seen signi ficantly influencing the density. Nutrients for their daily replenishment seen of negligible effect.

\section{The Environmental Impact Assess - ment (EIA) model}

Virtanen et al. (1994) describes the Environmental Impact Assessment (EIA) model in detail.

\section{The model calculations \\ Water masses}

The water masses are treated as horizontal layers interfaced by levels at selected depths. In the horizontal plane the model area is subdivided into rectangles with arbitrary mesh intervals in both directions. Explicit finitedifference schemes are used for the numerical solution of flow velocities and of water level elevations. Mathematically, the physical interact ions and mechanisms affecting water currents are described with Reynold's equations of motion, with the equation of hydrostatic pressure as a proper approximation of its vertical compon ents and with the equation of 
continuity(1):

$$
\begin{aligned}
& \frac{\partial \iota}{\partial}=-\nabla \cdot p / \rho_{o}+\nabla \cdot(K \cdot \nabla) u-2 \Omega u-u \cdot \nabla u+F \\
& \left.P=P_{a}+g \cdot(\eta-z) \cdot \rho_{o}+g\right]_{z}^{\eta}\left(\rho+\rho_{o}\right) d z \text { where: } \mu- \\
& \frac{\partial \iota}{\partial}+\frac{\partial}{\partial}+\frac{\partial v}{\partial z}=0
\end{aligned}
$$

flow velocity vector $(\mu, \mathrm{v}, \mathrm{w}), \eta$-water level elevation, $\mathrm{P}$-pressure, $\rho_{o}$-average water density, $\Omega$-angular velocity of the earth rotation, $p_{a}$-air pressure, $\mathrm{K}$ dispersion matrix of momentum, $\mathrm{g}$ gravity acceleration, $\mathrm{F}$-external forcing vector $=(0,0,-\mathrm{g})$.

The water currents are calculated with the 3D multi-layer (Simons, 1980; Virtanen et al., 1986; Koponen et al., 1992).

The calculation of water currents is detached from that of transport and water quality (Virtanen and Koponen, 1985; Halfon et al., 1990; Koponen et al., 1992).

The flow fields $\mathrm{U}^{\mathrm{L}}$ induced by winds $\mathrm{W}$ and water discharges $\mathrm{Q}$ are calculated in advance from several levels of water surface $\eta_{L}$. When the water level is changed, the flow fields for transport calculation changed accordingly. The surface area covered with water is updated. For any water level $\eta$ between two levels of flow field calculati $\eta_{L}$ and $\eta_{L+1}$ the flow field Ui.e. the flow velocities $u=(u, v, w)$ at every location $(m, n, k)$ of the $3 \mathrm{D}$ grid will be :

$$
U=\frac{\eta-\eta_{L+1}}{\eta_{L}-\eta_{L+1}} \cdot U^{L}+\frac{\eta_{L}-\eta}{\eta_{L}-\eta_{L+1}} \cdot U^{L+1}
$$

\section{Calculation of water quality}

Release, transport, mixing, resettling and the changes of water quality and bottom properties are coupled with each other in a most complex net of interactions. In the model these are gathered within the transport equation, with internal loading as one of its boundary conditions (Eq. 3):

$\frac{\partial}{\partial}=-u^{s} \frac{\partial}{\partial x}-v^{s} \frac{\partial}{\partial y}-w^{s} \frac{\partial}{\partial}+\frac{\partial}{\partial x}\left(D_{x} \frac{\partial}{\partial x}\right)+\frac{\partial}{\partial y}\left(D_{y} \frac{\partial}{\partial y}\right)+\frac{\partial}{\partial z}\left(D_{z} \frac{\partial}{\partial z}\right)+$ $+d q L / d a+R(T, c, \ldots)$

$q L_{B}=E_{o}+E_{1}+E_{2}$

Where

$c$ - Concentration (or strength) of any quantity computed, $u^{s}, v^{s}, w^{s}$-flow velocity components obtained from Eq. 2., $D_{x}, D_{y}, D_{z}$-dispersion coefficient components of concentrations, $q L$ loading discharges (from point source $P$, rivers $\mathrm{R}$, drainage area $\mathrm{D}$, bottom $\mathrm{B}$ and through water surface A), $n$ - discharge direction co-ordinate, $R$ - changes from internal (biogeochemical) reactions within water.

In the solution, the simultaneous complex interactions are governed by considering each process after the other with its immediate consequences and going through all of the processes step by step with short intervals until the desired time period as the sum of the time-steps for each process is equally expired (Virtanen et al., 1994).

\section{Model data and initial conditions}

The in-flowing Mediterranean waters at the boundaries were calculated with an average current velocity of $8 \mathrm{~cm}$ $\mathrm{sec}^{-1}$. The wind data was obtained from the Egyptian Navy Meteorological station for the different months (Fig. 2).

\section{The model application in Mex Bay}

The model was calibrated for 4 different seasons (May 1992, July 1993, October 1994 and February 1995), on a point, where measurements were available. Modelled results and field data were compared. 


\section{Results and Discussion}

For numerical simulation Mex Bay is subdivided with equal mesh resolution of $300 \mathrm{~m}$ into 40 by 17 horizontal grid squares and in the vertical direction into 10 one meter thick layers. The amount of the discharge water from the Umum Drain is given as monthly constant input data for the model. The open boundary to the Mediterranean has a monthly constant concentration. The model bathymetry was obtained from the Admiralty Chart, by linear interpolation of the depth data into the model grid.

The simulation results of the nutrients and chlorophyll a are presented as pictures of horizontal concentration distribution on surface. Wind frequency distributions are shown in Fig. 2.

During May 1992, the predominant wind direction was NW and relatively less NE. In July 1993, the winds were less variable, mostly NW. A noticeable change occurred in October 1994, when the wind direction was dominated by NE, relatively less powerful in NW. Again in winter (February 1995), the strong winds were mostly of NW direction, less affective towards south and east.

The flow velocities, induced by several combination of wind, jet discharge water from Umum Drain and discharge water at the western part of the bay, as well as the partial effect of the main sewer of Alexandria at its eastern vicinity, are calculated with a time-step of 30 s for periods of almost 2 weeks.

To show the differences in the resultant flow patterns under the wind action, a case study is presented. The water mass is subjected to the free surface shear induced by a uniform and steady wind of 5-m sec ${ }^{-1}$, blowing from the main eight directions. The steady state circulation patterns at the sea surface are sketched in Fig. 3.

The simulation results of the model run for the different months are shown in Figures 4-8. The main indicators of water quality in the present study were the nutrients (ammonia, nitrate and phosphate). The phytopl ankton standing crop was expressed as biomass.

The results are shown as timeseries of their concentrations, as concentration maps, and as numerical values, ranging from smallest to maximum on the computer screen, expressing the development of concentrations with colours along a selected horizontal lines.

The spatial distribution of the nutrients and chlorophyll a obtained from the model results indicated that:

- under the north-westerly wind in May, the maximum concentrations were restricted to the area around the outlet. However, very high nitrate and ammonia concentrations were also seen to spread towards the west. The time series at the selected points reflected such pattern.

- the predominance of NE wind direction in July affected clearly the distribution patterns, maximum concentrations pushed to a narrow coastal zone, and a gradual decrease far from the shore and towards west. The time series data showed variability in ammonia and nitrate concentrations, while phosphate exhibited a very limited range of variation.

- in October, following the prevailing wind directions, three distribution patterns were observed. Variations of phosphate with the time series were still limited

- the jet effect of land run-off on ammonia distribution was seen in 14 February under the SN wind direction. 
High concentrations covered most of the bay. The distribution patterns changed on 17 February, with the reverse wind direction, maximum concentrations were located near the coast, extending towards the inner part of the bay.

- the characteristics of nutrient distrib utions on the surface were in signif icant connection with wind speed and direction.

- the spatial distribution of chlorophyll a was clearly influenced by the trans port processes and the jet effect of the discharged water. High concentrations were detected in front of the main outlet, as well as towards the western part of the bay, decreasing towards the open sea.

As shown in Fig. 9, the correspo nding spatial distribution of the standing crop was somewhat similar to the modelling results of chlorophyll a. However, noticeable deviations occur, mainly attributed to the effect of changing species composition, excha nge with the open sea flora and that coming from Lake Maryout. A compa rison of the model results and field data is shown in Fig. 10. In general term, the behaviour of the model results is rather similar to the field observations, and the calculated values correspond well with the real data, but their values were lower, and there are some differences between them. These might be for some reasons; *the model results represent the mean values of the grid squares of the whole bay.

*local irregulations in sampling can't be avoided.

*other land-based sources of nutrients in the bay are not included.

*water exchange at the model open boundaries, significantly influence the concentration values in the modelled area.

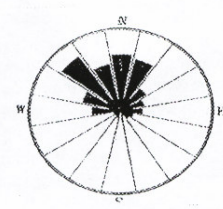

May 1992

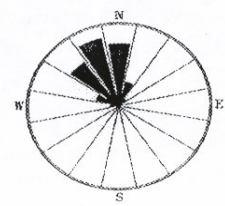

July 1993
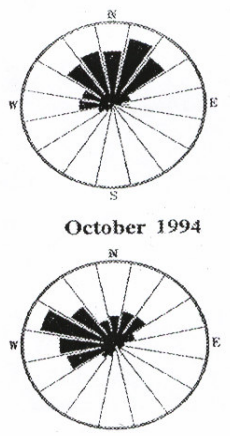

February 95

Figure 2. Wind frequency (\%) disrtibution over Mex Bay

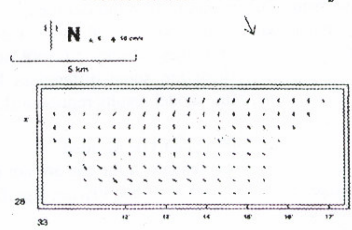

Figure 3. Modelled current field under a uniform and steady $5 \mathrm{~m} / \mathrm{sec}$ wind from NW 
*vertical mixing in the model is more intense compared to nature. Subsequently, the concentrations are distributed more rapidly in the vertical direction, causing reduction of concent rations in the surface layer.

*The ecological factors affecting the concentrations are not taken into account.

*the high supply from Umum Drain determines a prevalent $\mathrm{SN}$ gradient and a weaker NW gradient, persisting most of the time, but modified at times by prevailing meteo-climatic conditions. This powerful outflow creates a strong offshore surface current, and as a result there is a subsurface compensation current of higher salinity towards the coast (Labib, in preparation).

the species composition which creates sharp deviations between the counts and biomass.
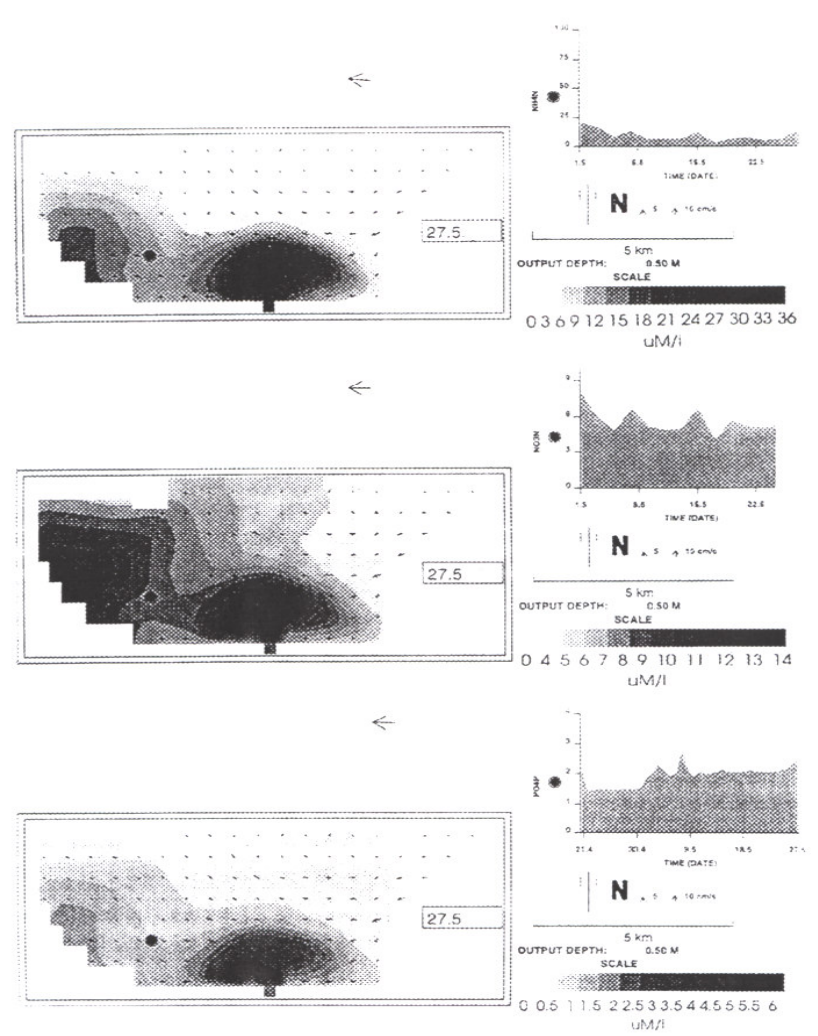

Figure 4. Model results. Horizontal distribution and time-series during May. 


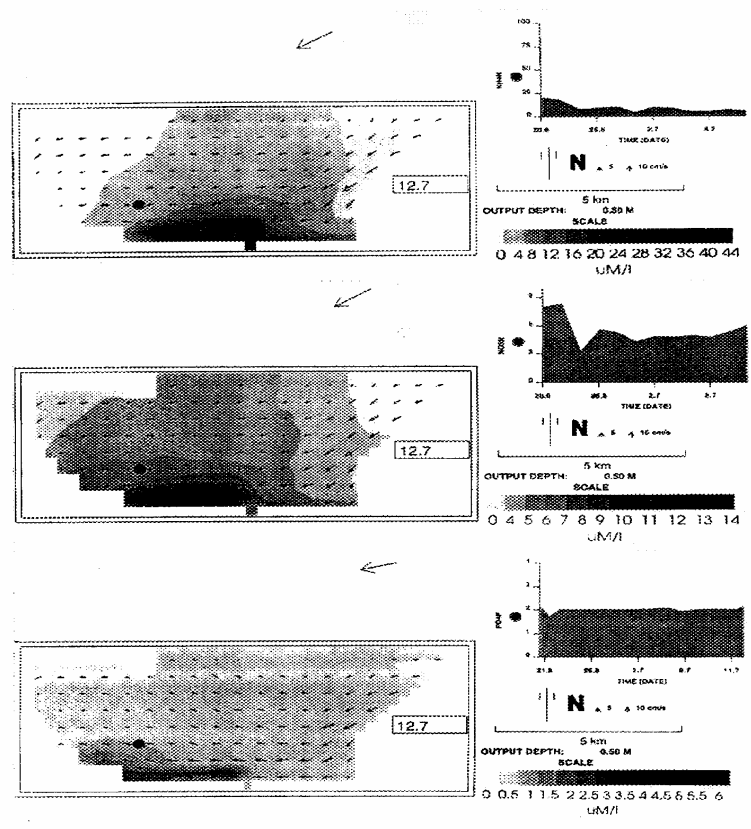

Figure 5. Model results. Horizontal distribution and time-series during July
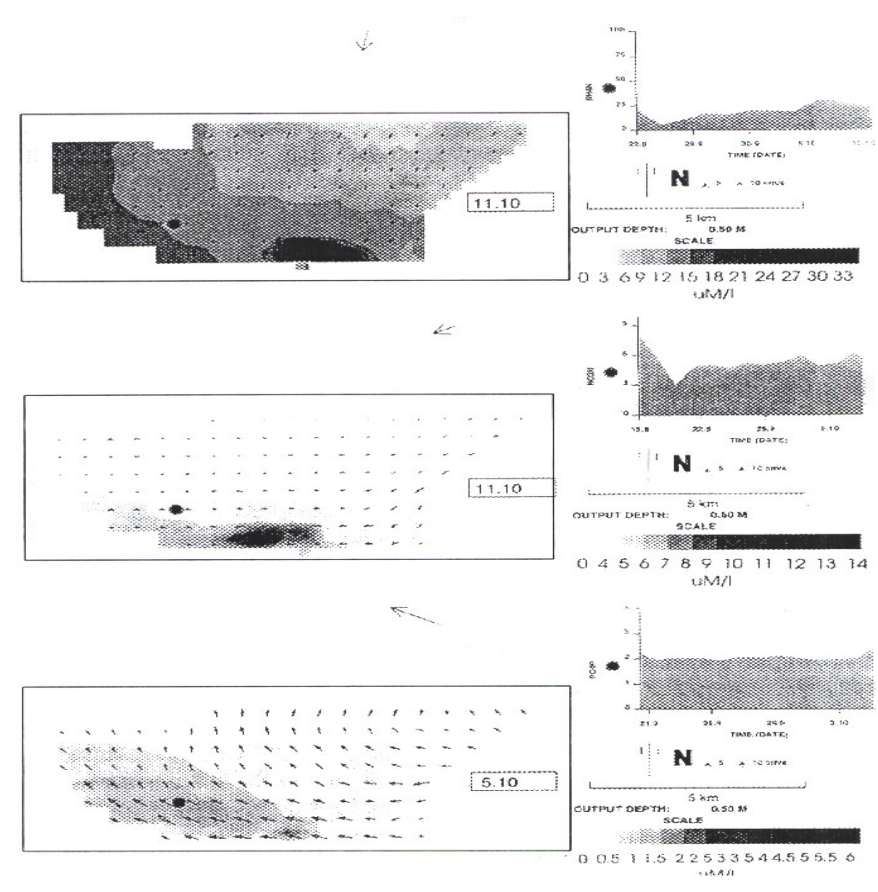

Figure 6. Model results. Horizontal distribution and time-series during October. 


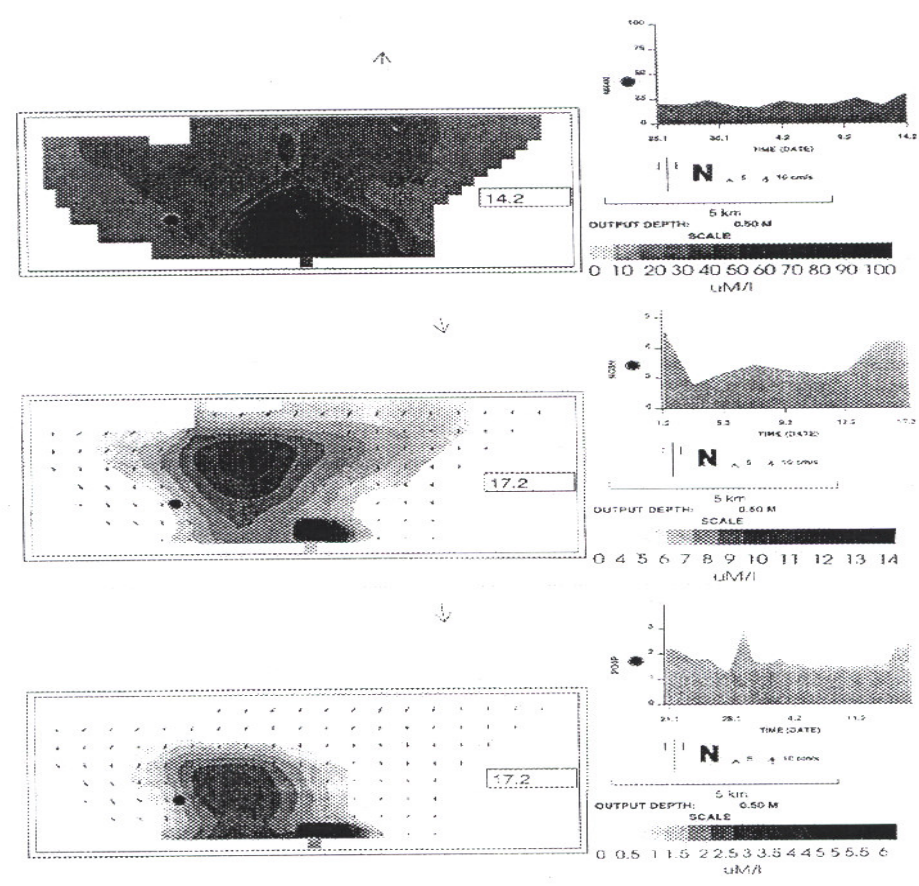

Figure 7. Model results. Horizontal distribution and time-series during February 1995.

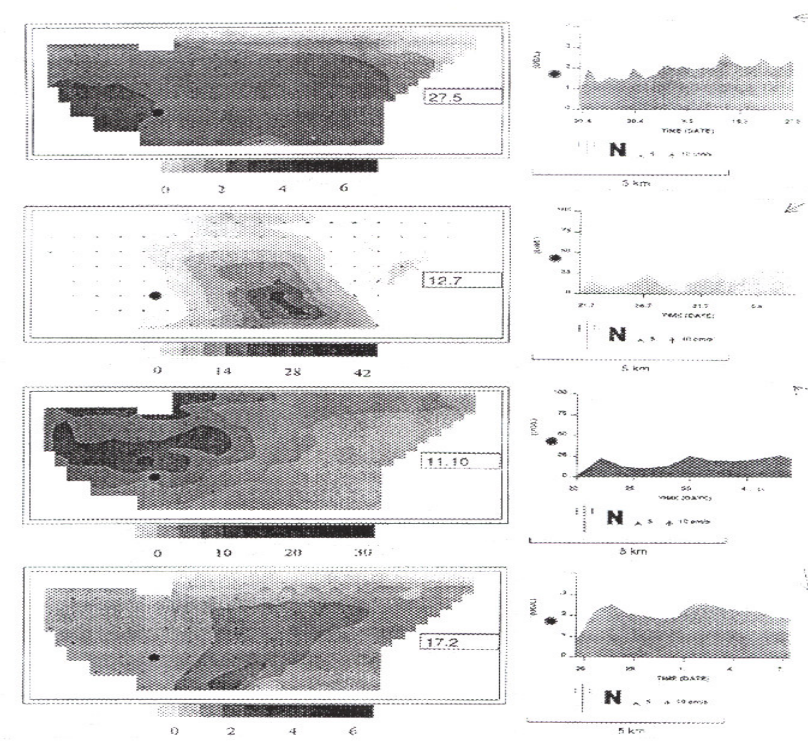

Figure 8. Model results. Horizontal distribution and time-series of chlorophyll $a$. 


\section{S.K.Mikhail, et al}

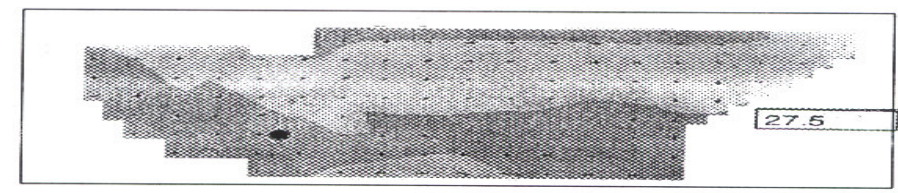

ॠ.

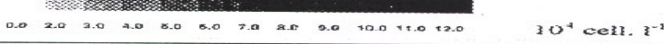

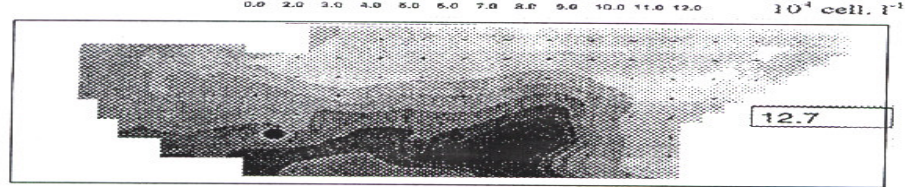

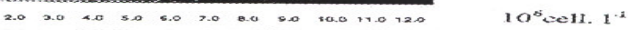

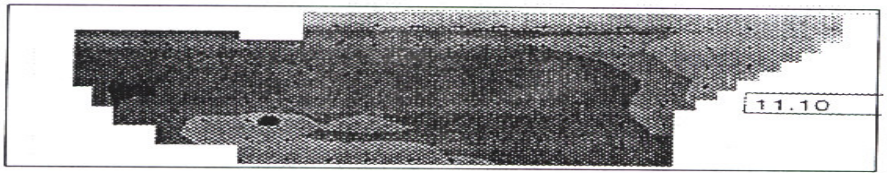

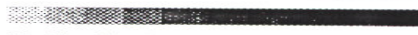

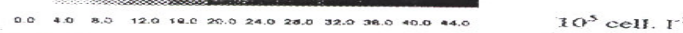

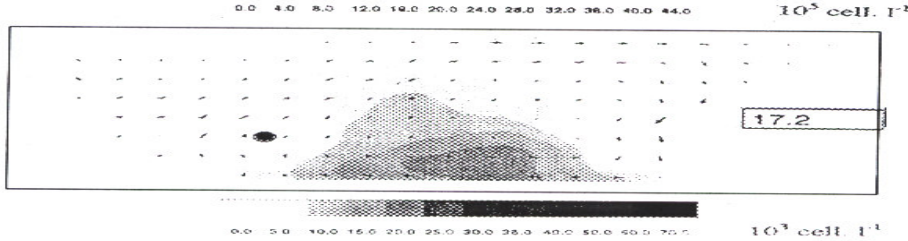

Figure 9. Spatial distribution of the standing crop
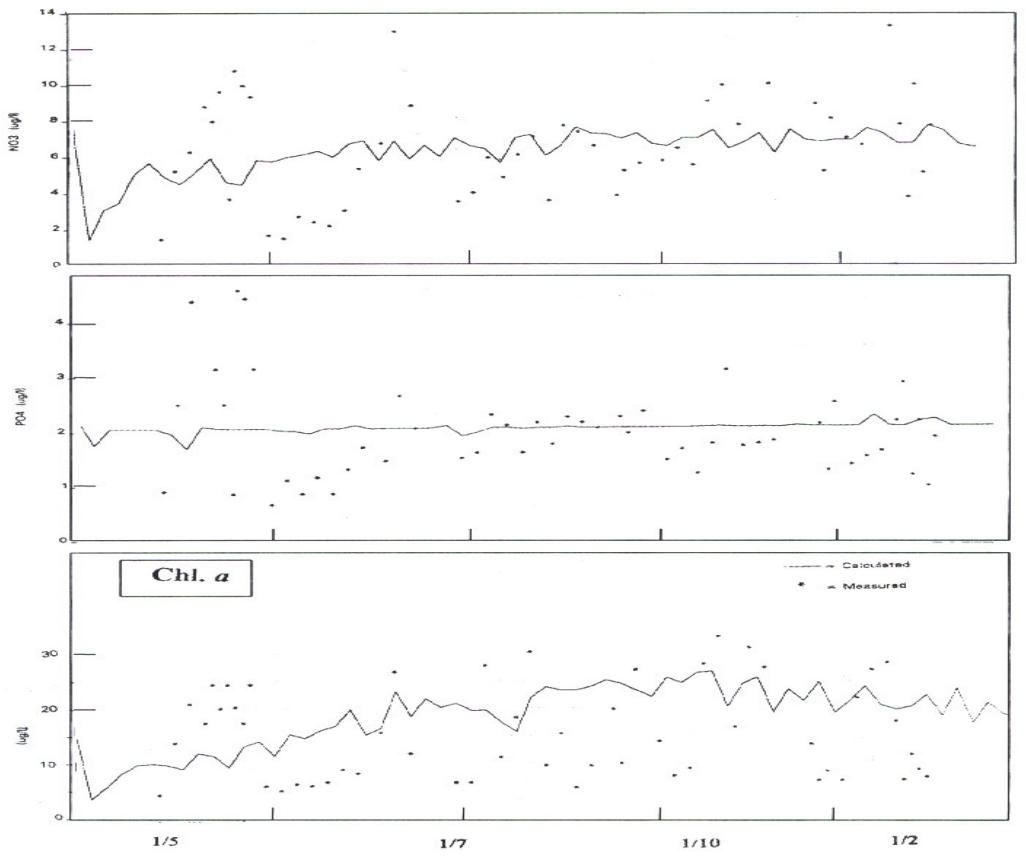

Figure 10. Modelling and field data measurements. 


\section{Conclusions}

The hydrodynamic and water quality model (the Environmental Impact Assessment model, EIA), with available field data, was applied to the highly eutrophic marine basin (Mex Bay). The bay, subjecting to a huge volume of discharge water, has distinct physical, chemical and biological aspects that easily differentiate it from the adjacent Mediterranean waters. The bay is a site of heavy algal blooms. The model was run for 4 different months during the period from 1992-1995, in order to follow the patterns of the spatial distribution of the dissolved inorganic nutrients, ammonia, nitrate and phosphate, and chlorophyll a. Generally, the calculated flow and concentrations corresponded well to observations and the model reacts logically to environmental changes. The model describes the seasonal variations of nutrients and chlorophyll a rather well. The largest deviations in the algal biomass results are observed in summer and autumn, affected mainly by the variability in species composition. A notable influence of the main outfall on the concentrations, reflecting a jet effect, was distinct. The concentrations decreased away from shore and towards the open sea. The western part of the bay, affected by transport processes, was denser and richer. Deviations are attributed to several reasons. Finer vertical resolution or stratification would be taken into account to reduce the vertical mixing. In future, the model must be tested and verified with extensive nutrient and phytoplankton data.

It is recommended that the load reduction of nutrients, particularly nitrogen and phosphorous, and the water discharge input are very important to overcome serious health, economic and environmental problems, not only in Mex Bay, but also along the coast of Alexandria. The increased frequency of visible algal blooms, including toxic species, associated with heavier Manmade eutrophication could lead to undesirable situations.

\section{Acknowledgement}

This work was done in the framework of LAND-3 Project "Protection of the Coastal Marine Environment in South Mediterranean", ICSC World Laboratory, Erice, Italy. We appreciate the help and discussion with our colleagues in this project.

\section{References:}

1. Abdel-Moneim, M.A; Khaled, A.M. and Iskander, M.F., 1994. A study of the levels of some heavy metals in Mex Bay, west of Alexandria, Egypt. The $4^{\text {th }}$ Conf. Environ. Prot. is a must, 10-12 May, 155-174.

2. Dorgham, M. M.; El-Samra, M.; Moustafa, M. I., 1987. Phytoplankton in an area of multi-polluting factors west of Alexandria, Eg. Qatar Univ. Sci., Bull., 7: 393-419.

3. ElSherif, Z. M., 1989. Distribution and ecology of phytoplankton in El-Mex Bay (Egypt). Bull. Inst. Oceanogr. Fish., A.R.E. 15 (2): 83-100.

4. Emara, H.L., Shiradah, M.A., Moustafa, T. H. and El-Deek, M. S., 1992. Effect of sewage and industrial wastes on the chemical characteristics of the Eastern Harbour and Mex Bay waters of Alexandria, Egypt. In: Marine coastal Eutrophication, Proc. Int. Conf. Bologna, Italy, 21-24 March, 1992 .Elsevier, 773-784.

5. Halfon, E.; Simons, T. J.; Scherzer, W. M., 1990. Modelling the spatial distribution of seven halocarbons on Lake St. Clair in June 1984 using the 
TOXFATE model. J. Great Lakes Res., 16: $90-112$.

6. Koponen, J.; Alasaarela, E; Lehtinen, K.; Sarkkula, J.; Simbierowics, P.; Vepsa, H.; Virtanen, M., 1992. Modelling the Dynamics of a Large Sea Area, Bothnian Bay Research Project 19881990. Publ. of the Water and Environment Research Institute, No 11, National Board of waters and the Environment, Helsinki, Finland, 73p.

7. Labib, W.,1992. Amphicrysis compressa Korshikov red tide bloom off Alexandria. Biology of the bloomand associated water chemistry. CERBOM, Centre d'etudes et de rech erches de biologie et d' Oceanographie. Tomes, 107-108: 13-23.

8. Labib, W.,1994 a. Ecological study of spring-early summer phytoplankton blooms in a semi-enclosed estuary. Chemistry and Ecology, 9: 75-85.

9. Labib, W.,1994 b. Massive algal pollution in highly eutrophic marine basin, Alexandria, Egypt. The $4^{\text {th }}$ Conf. of the Environ. Prot. is a must, 10-12 May 1994, 181-194.

10. Labib, W.,1996. Water discoloration in Alexandria, Egypt, April 1993. IOccurrence of Prorocentrum triestinum Schiller (Red Tide) bloom and associated physical and chemical conditions. Chemistry and Ecology, 12: 163-170.

11. Labib, W.,1997. Eutrophication In Mex Bay (Alexandria, Egypt) Environmental Studies And Statistical Approach.Bull. Nat.Inst. of Oceanogr.\&Fish., A.R.E.,23: 49-68.

12. Labib, W. and Halim, Y., 1995. Diel vertical migration and toxicity of Alexandrium minutum Halim red tide, in Alexandria, Egypt. Mar. life, 91: 1117.

13. Nessim, R.B., 1994. Environmental characteristics of Mex Bay. $1^{\text {st }}$ Proc. Arab cof. On Marine Environ. Protec. Alexandria, 5-7 February: 221-243.

14. Said, M. A.; El-Deek, M. S.; Mahmoud, Th. H. and Shridah, M. M. A., 1991. Physicochemical characteristics of different water types of El-Mex Bay, Alexandria, Egypt. Bull. Nat. Inst. Oceanogr. Fish., A.R.E., 17 (1): 103-116.

15. Samaan, A. A.; Abdella, R. R. and Gergis, W. L., 1992. Phytoplankton population in relation to hydrographic conditions along the West Coast of Alexandria (Egypt). Bull. Nat. Inst. Oceanogr. Fish., A.R.E., 18: 53-71.

16. Simons, T. J., 1980. Circulation Models of Lakes and Inland Seas. Can. Bull. Fish. Aquat. Sci., No 203. 145p.

17. Virtanen, M. and Koponen, J. 1985. Simulation of transport under irregular flow conditions. Aqua Fenn., 15 : 6575.

18. Virtanen, M.; Koponen, J.; Dahlbo, K.; Sarkkula, J., 1986. Threedimensional water quality transport model compared with field observations. Ecological Modelling, 31: 185-199.

19. Vitranen, M; Koponen, J.; Hellsten, S.; Nenonen, O.; Kinnunen, K., 1994. Principles for calculation of transport and water quality in strongly regulated reservoirs. J. Ecological Modelling, 74 : 103-123.

20. Vollenweider, R.A.,1981. Eutrophi cation- algal problem.WHO water Quel. Bull., 6. 


\section{تقييم عملية زيادة خصوبة مياه خليج المكس بالإسكندرية

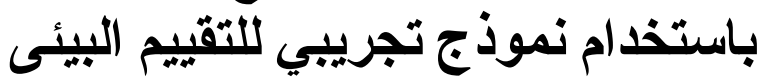

\section{*د/ سامية كامل ميخائيل- * ا.د / وجدى لبيب جرجس- **ث/إيمان

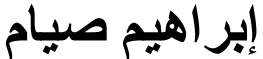 \\ 2معهد القومى لعلوم البحار \\ ** الاكاديمية العربية للعلوم و التكنولوجياو النقل البحرى قسم حماية البيئة البحرية}

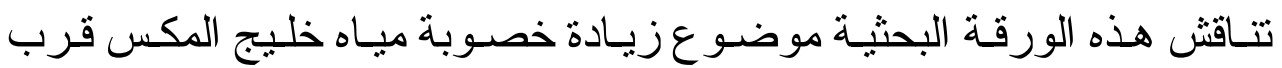

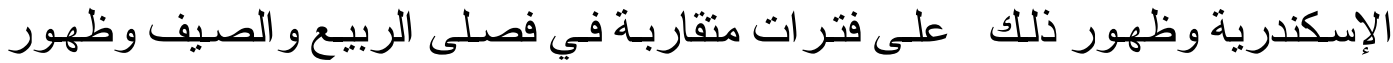

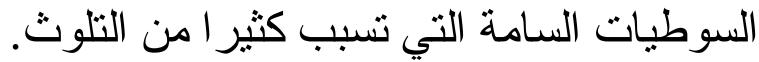

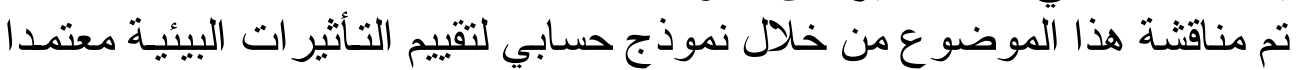

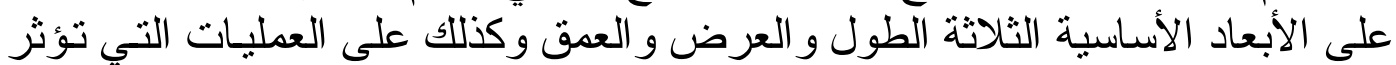
على حالة مياه البحر الإنيان. ويبدأ بقياس العو امل البيئية ثم تأثثير العو امل الخارجية، ويستخدم كذللك لتحفيز

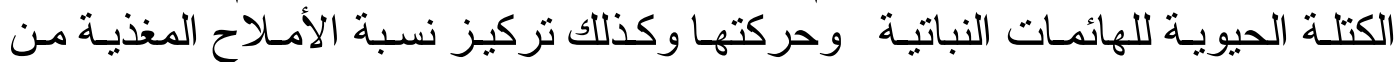

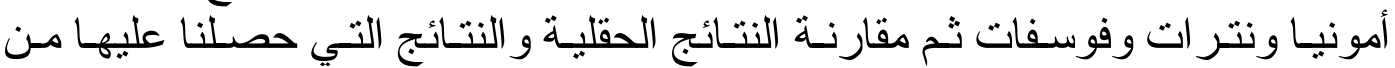

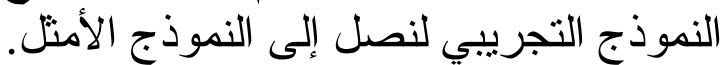

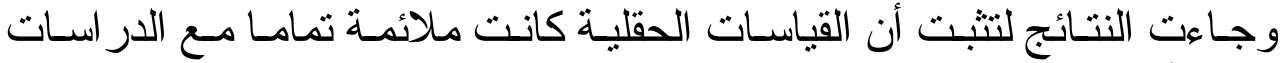

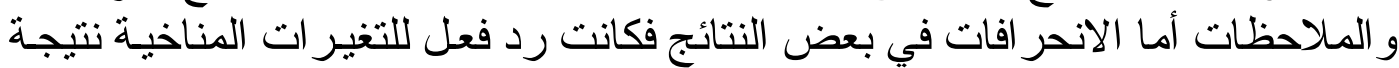

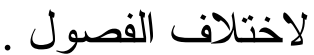
و أظهرت النتائج أيضـا أن توزيـع الهائمـات النباتيـة كـان ملازمـا لتركيز الكلوروفيل

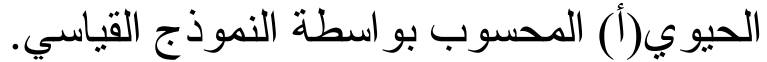

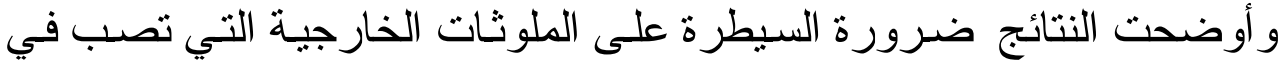

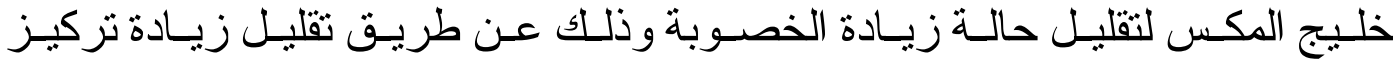
النيتزوجين و الفسفور في مياه الخليج. 